\title{
AN INVESTIGATION ON THE PRESERVATION OF KUNUN-ZAKI, AN AFRICAN FERMENTED CEREAL-BASED FOOD DRINK
}

\author{
N. A. Olasupo, ${ }^{a, c}$ A. F. OSIKOya, ${ }^{b}$ S. A. OdUnFa, ${ }^{b}$ A. O. KuBOyE ${ }^{b}$ \\ and O. OLATUNJI \\ ${ }^{\text {a }}$ Department of Botany and Microbiology, Lagos State University Ojo, \\ P. M. B. 1087 Apapa, Lagos. Nigeria \\ ${ }^{\mathrm{b}}$ Food and Biotechnology Division, Federal Institute of Industrial Research Oshodi (FIIRO), \\ P.M.B. 21023 Ikeja, Lagos. Nigeria
}

(Received: 17 January 2000; accepted: 4 May 2000)

\begin{abstract}
A study was conducted to evaluate the potential of combined processes of pasteurization and a chemical (sodium benzoate) for the preservation of kunun-zaki under ambient and refrigerated storage conditions. In the traditional preparation of kunun-zaki, spices proportion influenced the acceptability of the food product. Studies on the $\mathrm{pH}$ and the microbiological changes during the storage of preserved kunun-zaki at both storage conditions indicated that products under refrigeration temperature exhibited a more fairly stable $\mathrm{pH}(4.5$ to 4.9$)$ throughout the 21 day storage period. The kunun-zaki under room temperature storage had higher microbial loads with the appearance of coliforms and yeast and moulds on the 10th day. However, the appearance of these organisms were not found in products under refrigerated storage. Sensory evaluation test indicated that kunun-zaki under refrigeration temperature storage was still acceptable to the consumers, even up to the 21 st day. This study revealed a new possibility for the improvement of the shelflife of kunun-zaki (usually 24-36 h), without affecting its organoleptic properties for three weeks or more, with combined processes of pasteurization and additive such as sodium benzoate.
\end{abstract}

Keywords: kunun-zaki, fermented cereal food, preservation

Africa is presently passing through a developmental phase in which there is strong emphasis on local sourcing of raw materials. This awareness has transformed into a general interest in commercial processing of indigenous foods (SOPADE \& KASSUM, 1992). Kunun is a generic name among the Hausas in Nigeria for all types of nonalcoholic cereal-based beverages with specifications normally attached to denote the raw material source of its preparation and its sensory attribute(s). Hence, kunun-zaki simply means non-alcoholic beverage prepared from sorghum or millet grains, spiced

\footnotetext{
${ }^{\mathrm{c}}$ To whon the correspondence should be addressed
} 
with ginger, cloves and pepper and usually sweetened (ONUORAH et al., 1987). Traditionally, kunun-zaki is consumed in northern Nigeria by the Hausas (ADEYEMI \& UMAR, 1994), however because of its good refreshing property its consumption have been accepted across the entire region of Nigeria.

Kunun-zaki is popular because of its pleasantly sweet aroma and a mildy sour after-taste that it possesses. It is consumed for a number of reasons such as for refreshment, as appetizer (especially by the Muslim Hausa during the Ramadan fasting period), for toning down hunger when taking as snack and for entertainment in occasions where alcohol consumption is not allowed in the Northern Nigeria (INYANG \& DАВOT, 1997). The refreshing property and sweet aroma of kunun-zaki offers it the potential of a good local substitute to the industrially processed soft drinks in Nigerian environment.

Information on the microbiology of kunun-zaki showed that Lactobacillus plantarum and Bacillus subtilis were the predominant fermenting organisms, with Enterobacter spp. and Saccharomyces spp. occurring in small numbers (INYANG \& DABOT, 1997). Presently, in Nigeria, the preparation of kunun-zaki is still at the traditional stage where the basic processes are not standardized and the levels of spices are not quantified. Furthermore, a wide variation exists in the preparation procedure depending on taste and cultural habits, which partly explains the lack of consistency in product quality. Because of the primitiveness of the preparation of the food product, it is plagued with risk of contamination by spoilage organisms, which often contributes to its very short shelf life (24-36 h).

Previous effort aimed at improving the shelf life of kunun-zaki employed the use of pasteurization and sterilization (ADEYEMI \& UMAR, 1994; INYANG \& DABOT, 1997). However, these two preservation strategies could only improve the keeping quality of the product between 7 and 14 days even at refrigeration temperature. In view of this other means of preservation such as the use of chemical preservatives to attain a higher shelf-stability was suggested (INYANG \& DABOT, 1997). Keeping this in mind, the present study was conducted to explore means of extending the shelflife of kunun-zaki using the combined processes of pasteurization and sodium benzoate.

\section{Materials and methods}

\subsection{Preparation of kunun-zaki}

White variety of sorghum grain was purchased locally and processed in the traditional way for the preparation of kunun-zaki (Fig. 1). Two kilograms of clean sorghum grains were soaked in water for 2 days, after which it was washed by several water replacements before being wet-milled. This was followed by sieving and the 
resulting filtrate was allowed to settle. The supernatant was decanted and the settled slurry divided into two portions. One portion was mixed thoroughly with boiling water while the other portion was mixed with cold water. Into the boiling water-portion, $20 \mathrm{~g}$ of ground spice mixture (65\% ginger, $5 \%$ cloves and $30 \%$ pepper) was added. The two slurries (portions I \& II) were added together and mixed thoroughly, during which they were sweetened with sugar at $5 \%$ level. This mixture is called kunun-zaki and was allowed to ferment at room temperature $\left(28-30^{\circ} \mathrm{C}\right)$ for $12-18 \mathrm{~h}$. Equal volumes of fermented kunun-zaki were dispensed into sterile bottles for the preservation assay.

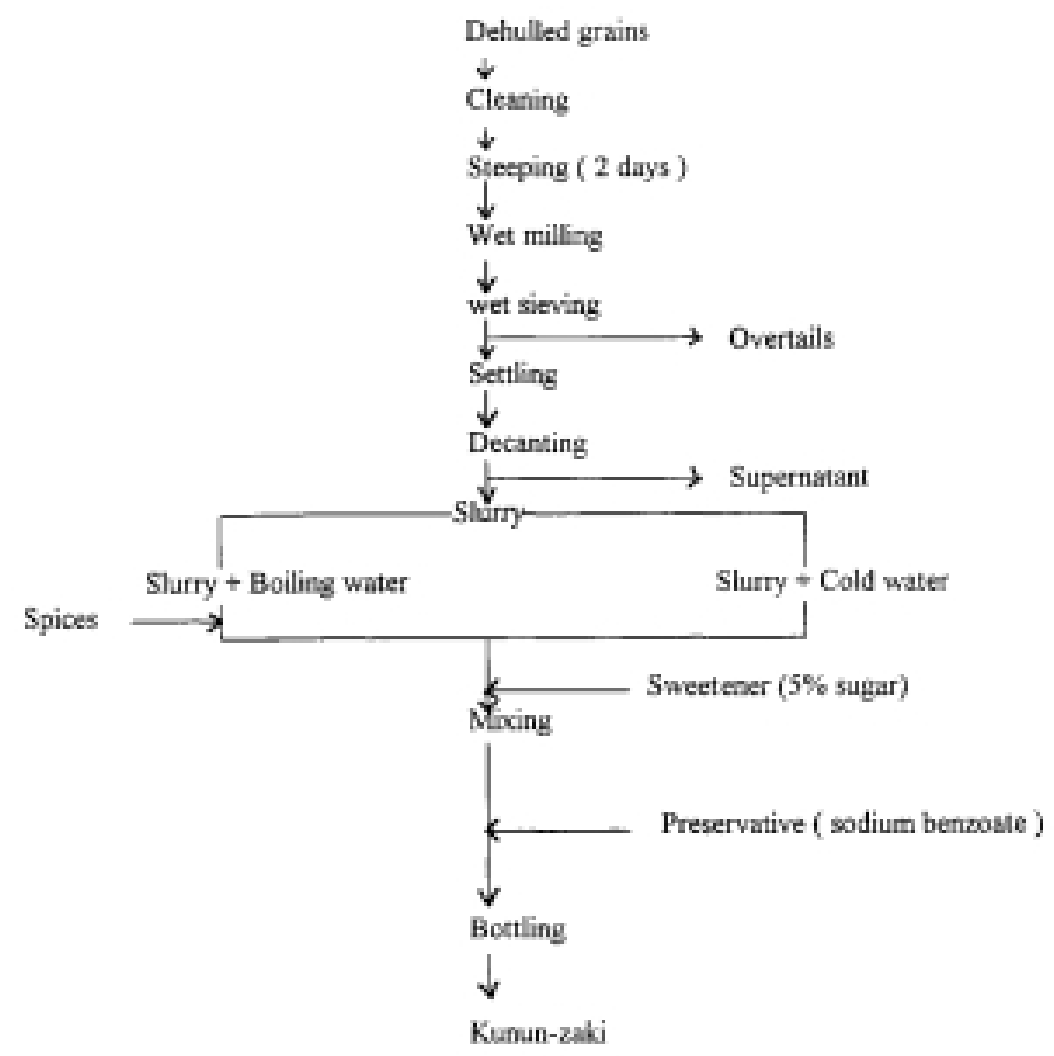

Fig. 1. Flow chart for the preparation on kunun-zaki 


\subsection{Preservation of kunun-zaki}

The bottles containing kunun-zaki samples to which sodium benzoate had been added at $0.1 \%$ level, were closed with a manual crowner and subjected to a heat treatment in a water bath at $60^{\circ} \mathrm{C}$ for $1 \mathrm{~h}$ with agitation of the bottled product every 5 min to promote heat transfer (BANIGO et al., 1987). A trial was done alongside with an open bottle to measure the temperature change rate. The reasons guiding the choice of the preservative used in the study have been previously highlighted (LUCK, 1992). The preserved food products were stored at both ambient (room) $\left(25-30{ }^{\circ} \mathrm{C}\right)$ and refrigeration temperatures $\left(8-10^{\circ} \mathrm{C}\right)$. The products were examined for indication of spoilage as well as changes in sensory properties.

\subsection{Chemical and microbial analysis}

The samples were analysed during storage for $\mathrm{pH}$ and microbial counts changes. The $\mathrm{pH}$ was determined using a digital $\mathrm{pH}$ meter (WTW pH 523 model). The microbial counts were done by serial dilution technique and spread plate method on malt extract agar containing $100 \mathrm{mg}$ chloramphenicol per litre for yeasts and moulds, violet red bile (VRB) agar for coliforms, and plate count agar for total viable counts (all from Oxoid). All cultures were incubated at $27-30^{\circ} \mathrm{C}$ for $3-5$ days and counts are determined per millilitre of material.

\subsection{Sensory evaluation}

The sensory attributes were evaluated using a 5-point Hedonic scale (where $1=$ dislike extremely and $5=$ like extremely) by 20 panelists selected from staff of the Food and Biotechnology Division of the Federal Institute of Industrial Research Oshodi (FIIRO), Lagos in Nigeria. All the panel members were familiar with kunun-zaki. Samples were served in numbered drinking glasses. Questionaires and water for mouth rinsing between each tasting were provided. The panelists were asked to read through the questionaires and the meaning of each attribute was explained to the panelist to avoid any misinterpretation. Tasters were not allowed to discuss their scores with one another during the evaluation session. Sensory parameters, such as consistency/thickness, mouthfeel, flavour, colour, sweetness, spiciness, and after taste were assessed. The scores were subjected to analysis of variance and Tukey's test (SNEDECOR, 1956) was employed to determine the degree of differences between the samples. 


\section{Results}

The chemical $(\mathrm{pH})$ and microbiological changes during storage of the preserved kunun-zaki under room and refrigeration temperatures are presented in Table 1.

Table 1

Chemical ( $p H)$ and microbiological changes during the storage of kunun-zaki preserved by pasteurization and sodium benzoate at different storage conditions

\begin{tabular}{|c|c|c|c|c|c|}
\hline \multirow{2}{*}{$\begin{array}{l}\text { Storage } \\
\text { duration } \\
\text { (day) }\end{array}$} & \multirow{2}{*}{$\begin{array}{l}\text { Storage } \\
\text { condition }\end{array}$} & \multirow[t]{2}{*}{$\mathrm{pH}$} & \multicolumn{3}{|c|}{ Microbiological parameter $\left(\mathrm{CFU} \mathrm{ml} \mathrm{m}^{-1}\right)$} \\
\hline & & & $\begin{array}{l}\text { Yeast \& mould } \\
\text { counts }\end{array}$ & $\begin{array}{c}\text { Total plate } \\
\text { counts }\end{array}$ & $\begin{array}{c}\text { Coliform } \\
\text { counts }\end{array}$ \\
\hline \multirow[t]{2}{*}{0 (freshly prepared) } & $\mathrm{R}$ & 4.5 & $1.8 \times 10^{5}$ & $4.9 \times 10^{5}$ & $2.6 \times 10^{5}$ \\
\hline & RF & 4.5 & $1.8 \times 10^{5}$ & $4.9 \times 10^{5}$ & $2.6 \times 10^{5}$ \\
\hline \multirow[t]{2}{*}{1} & $\mathrm{R}$ & 4.45 & $<100$ & $3.0 \times 10^{4}$ & $<100$ \\
\hline & RF & 4.45 & $<100$ & $1.0 \times 10^{4}$ & $<100$ \\
\hline \multirow[t]{2}{*}{2} & $\mathrm{R}$ & 4.45 & $<100$ & $3.0 \times 10^{4}$ & $<100$ \\
\hline & RF & 4.45 & $<100$ & $3.0 \times 10^{4}$ & $<100$ \\
\hline \multirow[t]{2}{*}{3} & $\mathrm{R}$ & 4.45 & $<100$ & $1.5 \times 10^{4}$ & $<100$ \\
\hline & RF & 4.45 & $<100$ & $5.0 \times 10^{3}$ & $<100$ \\
\hline \multirow[t]{2}{*}{4} & $\mathrm{R}$ & 4.75 & $<100$ & $7.0 \times 10^{4}$ & $<100$ \\
\hline & $\mathrm{RF}$ & 4.80 & $<100$ & $5.0 \times 10^{4}$ & $<100$ \\
\hline \multirow[t]{2}{*}{5} & $\mathrm{R}$ & 4.85 & $<100$ & $<100$ & $<100$ \\
\hline & RF & 4.90 & $<100$ & $<100$ & $<100$ \\
\hline \multirow[t]{2}{*}{6} & $\mathrm{R}$ & 4.75 & $<100$ & $<100$ & $<100$ \\
\hline & RF & 4.80 & $<100$ & $<100$ & $<100$ \\
\hline \multirow[t]{2}{*}{7} & $\mathrm{R}$ & 4.80 & $<100$ & $<100$ & $<100$ \\
\hline & RF & 4.85 & $<100$ & $<100$ & $<100$ \\
\hline \multirow[t]{2}{*}{8} & $\mathrm{R}$ & 3.60 & $<100$ & $<100$ & $<100$ \\
\hline & RF & 4.75 & $<100$ & $<100$ & $<100$ \\
\hline \multirow[t]{2}{*}{9} & $\mathrm{R}$ & 3.60 & $<100$ & $5.0 \times 10^{4}$ & $<100$ \\
\hline & $\mathrm{RF}$ & 4.80 & $<100$ & $<100$ & $<100$ \\
\hline \multirow[t]{2}{*}{10} & $\mathrm{R}$ & 3.60 & $3.8 \times 10^{5}$ & $8.2 \times 10^{7}$ & $2.0 \times 10^{3}$ \\
\hline & RF & 4.75 & $<100$ & $<100$ & $<100$ \\
\hline \multirow[t]{2}{*}{11} & $\mathrm{R}$ & 3.58 & $4.0 \times 10^{5}$ & $8.3 \times 10^{7}$ & $2.0 \times 10^{3}$ \\
\hline & RF & 4.85 & $<100$ & $<100$ & $<100$ \\
\hline \multirow[t]{2}{*}{12} & $\mathrm{R}$ & - & - & - & - \\
\hline & $\mathrm{RF}$ & 4.75 & $<100$ & $<100$ & $<100$ \\
\hline \multirow[t]{2}{*}{18} & $\mathrm{R}$ & - & - & - & - \\
\hline & RF & 4.75 & $<100$ & $<100$ & $<100$ \\
\hline \multirow[t]{2}{*}{21} & $\mathrm{R}$ & - & - & - & - \\
\hline & RF & 4.80 & $<100$ & $<100$ & $<100$ \\
\hline
\end{tabular}

R: room temperature; RF: refrigeration temperature; -: indicates values which were not determined because of spoilage and rejection/non acceptance by the consumer.

$<$ : below the detection limit 


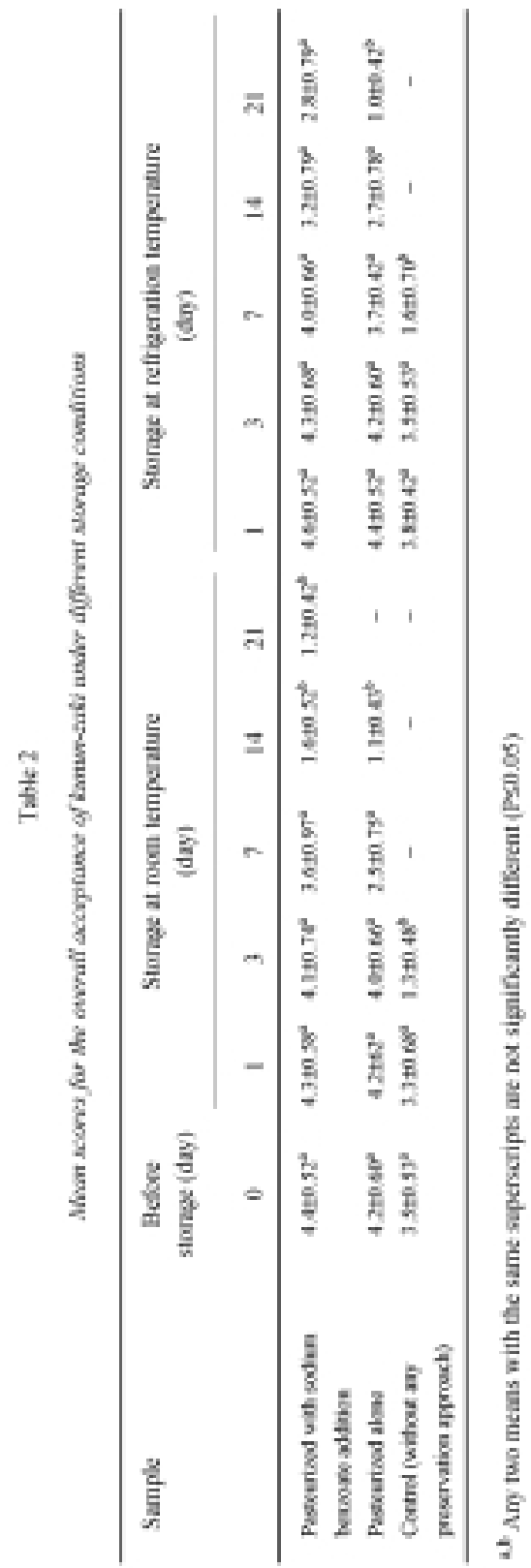

Acta Alimentaria 29, 2000 
The $\mathrm{pH}$ of products under refrigerated conditon was more stable ranging from 4.5 to 4.9 throughout the 21 day storage period. Samples under room temperature storage showed a decline in $\mathrm{pH}$ from 4.5 to 3.6 on the 8th and 9th day, which accounted for the acidic taste observation on these days. The microbiological examination indicated that both samples under room and refrigeration storage conditions gave no development of yeasts and moulds up till the 9th day, however on the 10th day, the appearance of these organisms was noticed only in samples stored at room temperature. No coliforms were found in products stored at refrigerated temperature by the method used. However, presence of coliforms was noticed after 9th day in kunun-zaki kept at room temperature. The total viable counts were lower in samples under refrigeration condition at the early days of storage (up till the 4th day), and got to a level below the detection limit $\left(<100 \mathrm{CFU} \mathrm{ml}{ }^{-1}\right)$ in samples under both storage conditions between the 5 th and 8th day. Thereafter while no count was observed in products under refrigerated condition, the total viable counts increased in samples stored at room temperature.

The sensory evaluation data are presented in Table 2. The kunun-zaki preserved by a combination of pasteurization and sodium benzoate addition and stored at refrigerated condition was still acceptable to the consumer on the 21 st day of storage in terms of overall sensory parameters considered in the study. The samples at room temperature storage were accepted by the consumer up till the 7th day, but was however rejected on the 14th day. However, samples preserved by pasteurization alone was only acceptable up till the 14th day under refrigeration condition and rejected thereafter. The control samples without any preservation approach were rejected by the tasters after $24 \mathrm{~h}$ of storage at room temperature and after 3 days at refrigerated temperature.

\section{Discussion}

The search for other means of preservation such as the use of chemical preservatives to attain a higher shelflife and portability of kunun-zaki have been advocated by previous authors (ADEYEMI \& UMAR, 1994; INYANG \& DABOT, 1997). The search becomes inevitable since all previous efforts such as pasteurization only (ADEYEMI \& UMAR, 1994) and pasteurization with sterilization (INYANG \& DABOT, 1997) could only extend the shelf life of kunun-zaki for a period between 7 and 14 days even at refrigerated storage condition. Hence the present report which established a technology for the preservation of kunun-zaki for a period exceeding three weeks, using the combined processes of pasteurization and sodium benzoate is noteworthy and could serve as a source of baseline information for future investigations on the use of chemical preservatives to improve the keeping quality of kunun-zaki and other non-alcoholic beverages in our environment. 
The improvement in the shelf life of kunun-zaki considered in our present study at both room and refrigerated storage conditions over those reported by previous workers as stated above, could be due to the use of a double attacking approaches of pasteurization and sodium benzoate on the spoilage organisms present in the food product. To our knowledge, the use of any chemical preservative for the preservation of kunun-zaki had not been reported in literature. Though some questions might have remained to be answered at the present stage, the results have demonstrated an approach for extending the shelf life of kunun-zaki for three weeks without any serious effects on the usual organoleptic properties of the beverage.

Dr. N. A. OLASUPO is grateful to the management of FIIRO Lagos/Nigeria for his appointment as a consultant to the institute during the period of the project.

\section{References}

ADEYEMI, I. A. \& UMAR, S. (1994): Effect of method of manufacture on quality characteristics of kununzaki, a millet-based beverage. Nig. Fd J., 12, 34-41.

BANIGO, O. I., AINA, A. \& OSSAI, G. A. (1987): The traditional burukutu manufacturing practice in Nigeria. J. Fd Agric., 2, 83-89.

INYANG, C. U. \& DABOT, Y. A. (1997): Storability and portability of pasteurized and sterilised kunun-zaki: a fermented sorghum beverage. J. Fd Process. Preserv., 21, 1-7.

LUCK, E. (1992): Food preservatives. IFI NR. 3, 49-56.

ONUORAH, S. I., ADESIYU, A. A. \& ADELEKE, J. O. (1987): Occurrence of Staphylococcus and coliforms in kunun-zaki and utensils used in its preparation in Samaru, Zaria. J. Fd Agric., 11, 31-34.

SOPADE, P. A. \& KASSUM, A. L. (1992): Rheological characterization of Nigerian liquid and semi-solid foods: kunun-zaki and kunun-gyada. Nig. FdJ., 10, 23-33.

SNEDECOR, R. W. (1956): Statistical methods. 5th ed., Iowa State College Press, Iowa. 